\title{
Unmet service needs evaluated by case managers among disabled patients on hemodialysis in Japan
}

This article was published in the following Dove Press journal: International Journal of Nephrology and Renovascular Disease

\section{Hidehiro Sugisawa' \\ Toshio Shinoda ${ }^{2}$ \\ Yumiko Shimizu ${ }^{3}$ \\ Tamaki Kumagai ${ }^{4}$ \\ Hiroaki Sugisaki \\ Seiji Ohira ${ }^{6, \dagger}$}

'Department of Gerontology, Graduate School of Gerontology, J. F. Oberlin University, Tokyo, ${ }^{2}$ Department of Medical Care Technology, Faculty of Medical and Health Science, Tsukuba International University, Tsuchiura, ${ }^{3}$ Department of Community Health Nursing, The jikei University School of Nursing, Chofu, ${ }^{4}$ Department of Fundamental Nursing, Graduate School of Nursing, Osaka City University, Osaka,

${ }^{5} \mathrm{Hachioji}$ Azumacho Clinic, Hachioji, Tokyo, ${ }^{6}$ Sapporo Kita Clinic, Sapporo, Hokkai-do, Japan

†Professor Dr. Seiji Ohira passed away on September 5, 2017

Correspondence: Hidehiro Sugisawa Graduate School of Gerontology, J. F. Oberlin University, 3758 Tokiwa-machi, Machida, Tokyo 194 0294, Japan Tel/Fax +8I 427979847

Email sugisawa@obirin.ac.jp
Background: This study aimed to investigate the levels of unmet needs for home and community-based services (HCBS) evaluated by case managers (CMs) among disabled patients on hemodialysis (DPHD) and to examine factors related to unmet needs. Unmet needs for HCBS were defined as situations in which patients do not use or underuse HCBS despite needing them. Candidates for the factors relating to unmet needs for HCBS included three dimensions: predisposing, enabling, and need factors.

Methods: Self-administrated questionnaires were collected from 391 CMs of DPHD certified with long-term care insurance. These were introduced by the dialysis facilities that a member of the Japanese Association of Dialysis Physicians belonged to. CMs were asked questions about their management of each individual case. HCBS included home help, visiting nursing, daycare, and short stay.

Results: The prevalence of unmet needs for each HCBS ranged from $32 \%$ for home help to $48 \%$ for short stay. Barriers to service usage in the patients were associated with unmet needs for all four services. The patients with more severe cognitive malfunction were more likely to have unmet needs for visiting nursing and short stay. Heavier burden with caregiving was associated with more likelihood of unmet needs for home help and short stay.

Conclusion: CMs need to monitor unmet needs after coordinating HCBS for DPHD and need to encourage HBCS use among patients with impaired cognitive function and caregivers with heavier caregiving burdens.

Keywords: disabled hemodialysis patients, long-term care, home and community-based services, Andersen's behavioral model, barriers to service usage, Japan

\section{Introduction}

Patients on dialysis are more likely to have physical disabilities. ${ }^{1-3}$ Furthermore, informal caregivers, mainly family caregivers who have a role in supporting disabled patients on dialysis, undergo deterioration in their own quality of life through caregiving. ${ }^{4,5}$ In Japan, as over $90 \%$ of patients on dialysis live in their own home, ${ }^{6}$ and patients on dialysis who need relatively high levels of medical care find it difficult to enter longterm care (LTC) facilities, ${ }^{7}$ disabled patients on dialysis and their informal caregivers need to cope with these stressful situations to continue living in their own home.

Home and community-based services (HCBS) are defined as programs and services delivered in a non-institutional setting to meet medical, daily living, and social needs among disabled persons, so that individuals can maintain independence in their communities. ${ }^{8}$ HCBS for older adults in Japan are provided based on LTC insurance established in 2000. Municipalities are the providers of LTC insurance and 
this system is financed by general taxes $(50 \%)$ and insurance premiums $(50 \%)$. It offers universal entitlement for every person aged 65 years and older, based on their physical and mental health needs, regardless of family income levels or the availability of caregivers. Accordingly, if disabled patients on dialysis are 65 years old and over, they can be certified as needing LTC. If they are under 64 years old, only patients with kidney disease induced by diabetes can be certified as needing LTC. The eligibility and nursing care levels (seven levels: two covering support needs and five levels of LTC) are assessed identically across Japan by the municipalities, based on objective procedures. HCBS, such as home help, in-home rehabilitation, and adult daycare, are provided by the system, while no monetary benefits are given. The price for each service is set by the government and is at an identical rate in different regions. The system allows a variety of service providers, including for-profit organizations, to enter certain areas of the LTC market after receiving certification from the municipalities. Beneficiaries are free to select not only the number and type of services but also the service providers they desire. The ceiling on the monetary amount of services that are used based on this system is determined by the level of their need. Beneficiaries pay either $10 \%$ or $20 \%$ of the total LTC service costs based on their income levels.

Case management fundamentally consists of an assessment of an individual's needs, developing care plans based on the assessment, accepting or arranging for HCBS as necessary, and monitoring/evaluating the care plan, although there are differences in case management systems because of different care settings and health systems across countries. ${ }^{9}$ As case management is equivalent to "care management" in Japan, this study uses the term case management. In Japan, case managers (CMs) were introduced as a new profession who would provide case management for the elderly needing care under the LTC insurance system. If disabled patients on dialysis are certified as needing LTC insurance by a regional government, the HCBS are arranged by CMs to prevent deterioration of the patients' quality of life. An unmet need is generally defined as a person needing help but not receiving any or enough help. ${ }^{10,11}$ Unmet needs have mainly been operationalized in two ways: inadequacy of assistance for activities of daily living (ADL)/instrumental ADL (IADL) tasks (in the following, unmet ADL/IADL needs) and lack of access to HCBS in persons who need to use them (in the following, unmet needs for HCBS). ${ }^{12}$ If CMs would effectively function to provide help that disabled people need/demand, it could be estimated that the prevalence of unmet needs is low. However, this indicator does not show good results.
According to a review by Dubuc et al, ${ }^{11}$ the prevalence of at least one unmet $\mathrm{ADL} / \mathrm{IADL}$ need has been estimated at between one-fifth and one-half, depending on the sample characteristics, the definition of unmet needs, and which ADL/IADL are considered. Why do unmet needs appear? According to a review by Dubuc et a ${ }^{11}$ and Liu et $a 1,{ }^{13}$ more ADL/IADL limitations, more chronic health conditions, being male, being a minority, having no spouse, living alone, lower family income, and limited insurance coverage were associated with increases in unmet ADL/IADL needs. Factors related to unmet needs for HCBS also resemble those unmet ADL/IADL needs. ${ }^{14}$

There are some limitations in previous studies on unmet needs in disabled persons and patients. First, studies on both unmet ADL/IADL needs and unmet needs for HCBS have mainly been limited to disabled persons and their informal caregivers. There have been only a few studies on unmet needs in patients with cancer, ${ }^{15-18}$ dementia, ${ }^{19-22} \mathrm{HIV}$ infection, ${ }^{23}$ and multiple sclerosis. ${ }^{24}$ Although patients on dialysis are likely to have ADL/IADL disability, there have been few studies on unmet needs among disabled patients on dialysis. According to our review, there are only a few studies on utilization of LTC services. ${ }^{25,26}$ Second, although there are some studies on unmet needs that were reported by disabled persons or their informal caregivers, there are few studies on unmet need reported by experts, especially CMs who are key persons to arrange HCBS use for persons needing help. Categories of social needs defined by Bradshaw ${ }^{27}$ include "normative needs", which refer to needs as defined by experts, "felt needs", which refer to what people feel they need, and "expressed needs", which refers to felt needs described by the patient. According to Bradshaw's categories, unmet need as articulated by experts is "normative unmet need". As experts assess need differently than patients do and neither is necessarily better than the other, ${ }^{28}$ we need to assess unmet needs as defined by experts. In addition, as studies indicate that the activities of CMs and social workers promote usage of HCBS, ${ }^{29,30}$ more knowledge of factors related to unmet needs from the point of view of CMs provides beneficial information to resolve unmet needs.

This study aimed to investigate the levels of unmet needs for HCBS evaluated by CMs among disabled patients on hemodialysis (DPHD) and to examine factors related to unmet needs. Disabled patients are defined in this study as those certified by LTC insurance. A condition certified by LTC insurance requires care on a continual and steady basis for complete or partial disabilities in basic daily activities because of physical or mental problems. This study focuses 
on hemodialysis as a type of dialysis. The main types of dialysis include hemodialysis and peritoneal dialysis, but hemodialysis patients are predominant, as they make up 95\% of all dialysis patients in Japan. ${ }^{31}$ Related factors are approached not only considering characteristics of patients but also the activities of CMs.

\section{Methods \\ Study subjects}

Caregivers of patients on hemodialysis certified by LTC insurance and their CMs in this study were selected through dialysis facilities whose doctors $(\mathrm{N}=949)$ belonged to the Japanese Association of Dialysis Physicians. A total of 113 dialysis facilities agreed to introduce candidates for participants and introduced 391 caregivers of DPHD and 397 CMs working for respective patients. The questionnaires for candidates for participants introduced by dialysis facilities were delivered through the dialysis facilities and CMs were asked about case management for each individual case. A total of 350 family caregivers and $391 \mathrm{CMs}$ returned completed questionnaires by mail. We analyzed the data from the $391 \mathrm{CMs}$ in this study.

\section{Measurements}

\section{Unmet needs for HCBS}

We distinguished between factors related to unmet needs for different types of services, because studies indicated that factors related to unmet service needs or service use differed by types of services. ${ }^{13,14,32}$ This study covered four types of HCBS: home help, visiting nurse, daycare, and short stay. CMs were asked about the current status of usage for each type of HCBS using the following four choices: "he/she doesn't use it now and doesn't need to use it", "although he/ she doesn't use it now, he/she needs to use it", "he/she uses it enough", and "although he/she uses it, he/she needs to use it more". We categorized participants who selected either "although he/she doesn't use it now, he/she needs to use it" or "although he/she uses it now, he/she needs to use it more" into the group with unmet needs for HCBS and categorized participants who selected either "he/she doesn't use it now and doesn't need it" or "he/she uses it enough" into the group without unmet needs for HCBS.

\section{Candidates for related factors}

There have been some studies that adopted Andersen's behavioral model $^{33}$ as an analytic framework to explain HCBS use. This model identifies three factors that influence service use: predisposing, enabling, and need factors. Predisposing factors focus on ones that incline toward persons' need of services and raise their subsequent perceptions of need and use of services (e.g., age, education, and health beliefs). Enabling factors are both community and personal resources to allow persons to use services (e.g., income, health insurance, a regular source of services, and travel and waiting times to access services). Need factors are persons' disabilities and illnesses that require services. This study examined the related factors based on this model. Age and sex of patients were included as predisposing factors. Enabling factors included the patient's financial/psychological barriers to service use, CMs' factors, organizational factors, and system factors that may influence CMs' performance. ${ }^{9}$ Factors were measured through the survey for CMs in this study. As a result, it was difficult to measure patient's characteristics including educational level and psychological conditions as related factors. This study adopted the same scales used in a study by Sugisawa et $\mathrm{al}^{34}$ that examined barriers to effective case management from this analytic model.

\section{Enabling factors}

Patients' financial/psychological barriers to service use were evaluated using three items, such as the patient having financial difficulties and the patient being reluctant to accept services were items composing the barriers scale. Choices consisted of four levels from "almost no problems" to "big problems". Scores for each item were assigned from 0 to 3 for the four levels and a scale score was calculated by dividing total scores of the three items by the number of items. The value of Cronbach's alpha for this scale was 0.745 .

As CMs' factors, lack of knowledge about dialysis and the period of case management for the patient were measured. Four items - lack of knowledge about medical management for dialysis, lack of knowledge about the possible complications related to dialysis, lack of knowledge about primary renal diseases, and lack of knowledge about medical conditions of their users - were used to evaluate lack of knowledge about dialysis. The choices and scoring of this scale were same as for the scale regarding the patient's financial and psychological barriers with regard to service use. The value of the Cronbach's alpha test of reliability of this scale was 0.930 . The period of case management for a patient was measured by asking the participants to choose the most appropriate term (the shortest period was "under six months," and the longest period was "ten years and over") as the period. The midpoint of each category was used for quantification.

Two items - very busy and a heavy case load - were used to evaluate organizational factors. The choices and scoring 
relating to this scale were the same as for the scale of patient's financial and psychological barriers in formal service use. Cronbach's alpha reliability value for this scale was 0.883 . System factors were evaluated on two aspects: lack of social resources and difficulties in coordination with stakeholders. A lack of social resources was evaluated by using five items, such as there being few providers of home visiting services and a lack of transportation options to dialysis facilities. Difficulties in coordination with stakeholders were evaluated by using seven items, such as poor communication with staff in the dialysis facilities and poor communication with staff in day service facilities. The choices and scoring relating to this scale were the same as for the scale of patient's financial and psychological barriers in service use. Cronbach's alpha reliability value for each scale was 0.723 and 0.933 .

\section{Need factors}

Need factors included not only patients' care need levels but also caregivers' mental and physical caregiving burden. ${ }^{35}$ Patients' care need levels were evaluated from four aspects: LTC level, physical malfunction, cognitive malfunction, and primary kidney disease. LTC level was classified into seven levels: two covering support needs and five levels of LTC. The scores assigned were 1 for the two levels of support need, and from 2 to 6 for the five ranks from level 1 to level 5 of LTC needs. Physical malfunction in the patient was assessed in terms of activities carried out during daily living, using the "degree of independent daily living for disabled elderly" criteria designated by the Japanese Ministry of Health, Labour and Welfare. The scores were assigned from 1 to 4 , for the four ranks from "no impairment" to "bedridden". Cognitive malfunction was measured by "degree of independent daily living for demented elderly" criterion, which is also designated by the Japanese Ministry of Health, Labour and Welfare. The scores on this variable were assigned from 1 to 6 for the six levels from "no cognitive impairment" to "severe impairment". Primary diseases of kidneys included three categories: chronic glomerulonephritis, diabetic nephropathy, and others. Caregivers' mental and physical caregiving burden was evaluated by asking CMs. Choices were composed of four levels from "no burden" to "heavy burden". Scores were assigned as 1 to 4 , for each of the four levels. Choices also involved "his/her family doesn't give care to the disabled patient". This choice was assigned 1 as "no burden".

\section{Statistical methods}

Logistic regression analyses were conducted separately by entering each unmet need for four types of HCBS as dependent variables and all the candidates for related factors as independent variables. Many cases had to be excluded from the sample because some of the variables used in the model had high levels of missing values. The number of cases that did not show missing values totaled 200 (51.2\% of final sample size). As Table 1 shows, the variables with highest missing values were primary kidney diseases $(28.6 \%)$, difficulties in communication with stakeholders (13.6\%), and physical malfunction (5.9\%). Other variables had missing values rates under 5\%. Participants that were excluded from analysis on this basis showed significant differences in only two variables: the ages of their patients and work overload compared to those without missing values. Nevertheless, we were concerned that deletion of cases with missing values could reduce the statistical power of the analysis. We therefore used multiple imputations to add all those cases that included variables with missing values into the analysis, using SPSS version 23 statistical software. Thus, we imputed estimated values for the missing values by entering all variables used in this study. The number of databases so affected was 20 .

\section{Ethical issues}

This study was conducted in line with the guidelines in the Declaration of Helsinki. All the procedures of the study were approved by the Research Ethics Board of J. F. Oberlin University. A letter explaining the contents and ethical considerations of the study was sent to all the dialysis facilities that we asked to introduce candidates for participation. At the same time, we sent each of the facilities survey request letters explaining the contents of the study and the ethical considerations that would be in place for the family caregivers of patients and for their CMs. We asked them to hand over the letters and to explain the contents and ethical considerations of the study to potential candidates for the survey when they recruited them.

The dialysis facilities that agreed to the survey informed us of the number of "both the family caregivers and their CMs who expressed a willingness to participate in the survey", "only the caregivers who expressed a desire to participate in the survey", and "only the CMs who expressed the desire to participate in the survey". We then sent the facilities the appropriate number of survey request letters and selfadministrated questionnaires. In those cases where both the family members and their CMs had expressed the desire to participate in the survey, the questionnaires were given the same ID number to merge the responses of the family caregivers and their CMs. Participants of the family caregivers and their CMs sent already answered questionnaires to us 
Table I Summary statistics for the variables

\begin{tabular}{|c|c|c|c|c|}
\hline Variables & $\begin{array}{l}\text { Missing } \\
\text { values (\%) }\end{array}$ & $\begin{array}{l}\text { Categories/ } \\
\text { values of the characteristics }\end{array}$ & $\begin{array}{l}\text { Before } \\
\text { imputation }\end{array}$ & $\begin{array}{l}\text { After } \\
\text { imputation }\end{array}$ \\
\hline \multicolumn{5}{|l|}{ Unmet need } \\
\hline \multirow[t]{6}{*}{ Home help } & 2.3 & Unmet need & 31.7 & 31.6 \\
\hline & & He/she does not use it now and does not need to use it & 19.1 & 19.0 \\
\hline & & He/she uses it now and needs to use it more than now & 12.6 & 12.6 \\
\hline & & Met need & 68.3 & 68.4 \\
\hline & & $\mathrm{He} / \mathrm{she}$ does not need it now & 34.3 & 34.1 \\
\hline & & He/she uses it now and does not need to use it more than now & 34.0 & 34.3 \\
\hline \multirow[t]{6}{*}{ Visiting nursing } & 4.6 & Unmet need & 34.5 & 36.1 \\
\hline & & $\mathrm{He} /$ she does not use it now and does not need to use it & 34.2 & 33.4 \\
\hline & & He/she uses it now and needs to use it more than now & 0.3 & 2.7 \\
\hline & & Met need & 65.5 & 63.9 \\
\hline & & $\mathrm{He} / \mathrm{she}$ does not need it now & 48.3 & 47.3 \\
\hline & & He/she uses it now and does not need to use it more than now & 17.2 & 16.6 \\
\hline \multirow[t]{6}{*}{ Daycare } & 2.3 & Unmet need & 37.5 & 37.1 \\
\hline & & $\mathrm{He} / \mathrm{she}$ does not use it now and does not need to use it & 28.3 & 28.0 \\
\hline & & $\mathrm{He} / \mathrm{she}$ uses it now and needs to use it more than now & 9.2 & 9.1 \\
\hline & & Met need & 62.5 & 62.9 \\
\hline & & $\mathrm{He} / \mathrm{she}$ does not need it now & 19.6 & 20.0 \\
\hline & & $\mathrm{He} / \mathrm{she}$ uses it now and does not need to use it more than now & 42.9 & 42.9 \\
\hline \multirow[t]{6}{*}{ Short stay } & 3.8 & Unmet need & 47.9 & 47.8 \\
\hline & & $\mathrm{He} / \mathrm{she}$ does not use it now and does not need to use it & 43.9 & 43.1 \\
\hline & & He/she uses it now and needs to use it more than now & 4.0 & 4.7 \\
\hline & & Met need & 52.1 & 52.2 \\
\hline & & He/she does not need it now & 44.4 & 44.1 \\
\hline & & He/she uses it now and does not need to use it more than now & 7.7 & 8.1 \\
\hline \multicolumn{5}{|l|}{ Predisposing factors } \\
\hline Age of clients (years) & 0.0 & Mean (SD) & $76.3(8.67)$ & $76.3(8.67)$ \\
\hline \multirow[t]{2}{*}{ Sex of clients } & 0.0 & Male (\%) & 53.7 & 53.7 \\
\hline & & Female & 46.3 & 46.3 \\
\hline \multicolumn{5}{|l|}{ Enabling factors } \\
\hline $\begin{array}{l}\text { Barriers to service usage in the } \\
\text { patient }\end{array}$ & 3.1 & Mean (SD) & $0.57(0.66)$ & $0.58(0.66)$ \\
\hline $\begin{array}{l}\text { Lack of knowledge of dialysis in } \\
\text { case managers }\end{array}$ & 1.5 & Mean (SD) & $0.86(0.74)$ & $0.86(0.74)$ \\
\hline $\begin{array}{l}\text { Period of case management for } \\
\text { the patient (years) }\end{array}$ & 0.3 & Mean (SD) & $2.91(2.60)$ & $2.91(2.59)$ \\
\hline Work overload & 2.3 & Mean (SD) & $0.55(0.76)$ & $0.56(0.76)$ \\
\hline $\begin{array}{l}\text { Lack of social resources in the } \\
\text { community }\end{array}$ & 2.3 & Mean (SD) & $0.82(0.65)$ & $0.82(0.65)$ \\
\hline $\begin{array}{l}\text { Lack of communication with } \\
\text { stakeholders }\end{array}$ & 13.6 & Mean (SD) & $0.4 I(0.66)$ & $0.44(0.64)$ \\
\hline \multicolumn{5}{|l|}{ Need factors } \\
\hline \multirow[t]{3}{*}{ Primary diseases of kidneys } & 28.6 & Chronic glomerular nephritis (\%) & 20.8 & 21.1 \\
\hline & & Diabetic nephropathy & 68.5 & 66.0 \\
\hline & & Others & 10.8 & 12.9 \\
\hline Nursing care level & 0.5 & Mean (SD) & $3.59(1.34)$ & $3.59(1.34)$ \\
\hline $\begin{array}{l}\text { Physical malfunction of the } \\
\text { patient }\end{array}$ & 5.9 & Mean (SD) & $2.45(0.84)$ & $2.46(0.83)$ \\
\hline $\begin{array}{l}\text { Cognitive malfunction of the } \\
\text { patient }\end{array}$ & 0.3 & Mean (SD) & $2.18(1.22)$ & $2.19(1.22)$ \\
\hline $\begin{array}{l}\text { Caregiver's burden with } \\
\text { caregiving }\end{array}$ & 1.0 & Mean (SD) & $2.57(0.82)$ & $2.56(0.82)$ \\
\hline $\mathrm{N}$ & 391 & & & \\
\hline
\end{tabular}


by mail. In this study, return of questionnaires by mail from candidates meant consent for survey participation.

These data collection procedures assured the confidentiality of self-administered, anonymous questionnaires. Finally, we did not obtain information about names and addresses of people who participated in this survey.

\section{Results}

\section{Summary statistics for variables and the prevalence of unmet need for HCBS}

Table 1 shows the summary statistics before and after multiple imputations. There were few differences in the distributions between the before and after multiple imputations. In the data derived from the multiple imputations, the average age of patients was 76.3 years, and $53.7 \%$ of the participants were males. Diabetic nephropathy and chronic glomerulonephritis affected $66.0 \%$ and $21.1 \%$ of the participants, respectively, as primary kidney diseases. The average period of case management for a patient was 2.91 years. The prevalence for each of respite short stay, daycare, visiting nursing, and home help was $47.8 \%, 37.1 \%, 36.1 \%$, and $31.6 \%$, respectively.

\section{Factors related to unmet needs for HCBS}

Tables 2-5 show the influence of the related factors on unmet need for each HCBS, using data created after multiple imputations. Among the predisposing factors, male patients had a higher prevalence of unmet need for daycare service compared with females. Among enabling factors, barriers to service usage in the patient were significantly related to unmet need for all four HCBS: home help, visiting nurse, daycare, and short stay. Poor knowledge of dialysis and shorter period of case management for the patient were also related to unmet need for home help service and daycare. Among need factors, cognitive malfunction of the patient was significantly related to unmet needs for visiting nursing and short stay. Caregiver's caregiving burden was also significantly related to unmet needs for home help and short stay. Finally, there were few differences in the results between the datasets created from multiple imputations and those that were used without multiple imputations.

\section{Discussion}

Although what impact unmet needs for HCBS have in DPHD remains unclear, some studies indicate that unmet needs in disabled older adults had a significant influence on their and their family's health status and well-being. ${ }^{14,36}$ Accordingly, it is highly possible for unmet need to have produced the
Table 2 Factors related to unmet needs for home help: logistic regression analysis

\begin{tabular}{|c|c|c|c|}
\hline \multirow[t]{2}{*}{ Variables } & Categories & $\begin{array}{l}\text { After } \\
\text { imputation }\end{array}$ & $\begin{array}{l}\text { Before } \\
\text { imputation }\end{array}$ \\
\hline & & $\begin{array}{l}\text { Odds ratio } \\
(95 \% \mathrm{Cl})\end{array}$ & $\begin{array}{l}\text { Odds ratio } \\
(95 \% \mathrm{Cl})\end{array}$ \\
\hline Age of clients & & $\begin{array}{l}1.02 \\
(0.99,1.05)\end{array}$ & $\begin{array}{l}1.02 \\
(0.98,1.06)\end{array}$ \\
\hline Sex of clients & $\begin{array}{l}\text { Female }(=\text { ref }) \\
\text { Male }\end{array}$ & $\begin{array}{l}- \\
0.75 \\
(0.47,1.21)\end{array}$ & $\begin{array}{l}- \\
0.97 \\
(0.50,1.86)\end{array}$ \\
\hline $\begin{array}{l}\text { Barriers to service } \\
\text { usage in the patient }\end{array}$ & & $\begin{array}{l}1.82 * * \\
(1.21,2.74)\end{array}$ & $\begin{array}{l}1.68 \\
(0.95,2.98)\end{array}$ \\
\hline $\begin{array}{l}\text { Lack of knowledge } \\
\text { of dialysis in case } \\
\text { managers }\end{array}$ & & $\begin{array}{l}1.64^{*} \\
(1.09,2.46)\end{array}$ & $\begin{array}{l}2.66^{* *} \\
(1.49,4.77)\end{array}$ \\
\hline $\begin{array}{l}\text { Period of case } \\
\text { management for the } \\
\text { patient }\end{array}$ & & $\begin{array}{l}0.96 \\
(0.88,1.06)\end{array}$ & $\begin{array}{l}0.94 \\
(0.82,1.07)\end{array}$ \\
\hline Work overload & & $\begin{array}{l}1.01 \\
(0.69,1.48)\end{array}$ & $\begin{array}{l}1.00 \\
(0.62,1.63)\end{array}$ \\
\hline $\begin{array}{l}\text { Lack of social } \\
\text { resources in the } \\
\text { community }\end{array}$ & & $\begin{array}{l}1.30 \\
(0.80,2.12)\end{array}$ & $\begin{array}{l}1.27 \\
(0.66,2.47)\end{array}$ \\
\hline $\begin{array}{l}\text { Lack of communication } \\
\text { with stakeholders }\end{array}$ & & $\begin{array}{l}0.54 * \\
(0.31,0.95)\end{array}$ & $\begin{array}{l}0.36^{* *} \\
(0.16,0.77)\end{array}$ \\
\hline $\begin{array}{l}\text { Primary diseases of } \\
\text { kidneys }\end{array}$ & $\begin{array}{l}\mathrm{CGN} \text { (=ref) } \\
\mathrm{DN}\end{array}$ & $\begin{array}{l}- \\
1.77 \\
(0.86,3.63)\end{array}$ & $\begin{array}{l}- \\
2.26 \\
(0.94,5.44)\end{array}$ \\
\hline & Others & $\begin{array}{l}1.22 \\
(0.38,3.95)\end{array}$ & $\begin{array}{l}1.58 \\
(0.40,6.24)\end{array}$ \\
\hline Nursing care level & & $\begin{array}{l}0.96 \\
(0.75,1.23)\end{array}$ & $\begin{array}{l}1.12 \\
(0.80,1.57)\end{array}$ \\
\hline $\begin{array}{l}\text { Physical malfunction of } \\
\text { the patient }\end{array}$ & & $\begin{array}{l}0.97 \\
(0.65,1.45)\end{array}$ & $\begin{array}{l}0.84 \\
(0.48,1.49)\end{array}$ \\
\hline Cognitive malfunction & & 1.05 & 0.96 \\
\hline of the patient & & $(0.84,1.32)$ & $(0.71,1.30)$ \\
\hline Caregiver's burden & & $1.62 * *$ & 1.26 \\
\hline with caregiving & & $(1.18,2.24)$ & $(0.82,1.92)$ \\
\hline Model $\chi^{2}(=d f)$ & & $48.7(14)^{* * *}$ & $27.7(14)^{*}$ \\
\hline $\mathrm{N}$ & & 391 & 207 \\
\hline
\end{tabular}

Note: $* P<0.05 ; * * P<0.01$; $* * * P<0.001$.

Abbreviations: CGN, chronic glomerular nephritis; $\mathrm{Cl}$, confidence interval; DN, diabetic nephropathy.

same problems among DPHD. In this study, the prevalence of unmet needs for HCBS was higher than in previous studies on other disabled older adults: $48 \%, 37 \%, 36 \%$, and $32 \%$ for short stay, daycare, visiting nursing, and home help, respectively. Some studies have explored the prevalence of unmet needs for HCBS among disabled older adults. According to a study in the US by Casado et al ${ }^{14}$ the prevalence of unmet needs for each of community-based program (e.g., daycare service), respite care, home help, and home-based programs (e.g., visiting nursing) reported by caregivers for 
Table 3 Factors related to unmet needs for visiting nursing: logistic regression analysis

\begin{tabular}{|c|c|c|c|}
\hline \multirow[t]{2}{*}{ Variables } & \multirow[t]{2}{*}{ Categories } & \multirow{2}{*}{$\begin{array}{l}\begin{array}{l}\text { After } \\
\text { imputation }\end{array} \\
\text { Odds ratio } \\
(95 \% \mathrm{Cl})\end{array}$} & \multirow{2}{*}{$\begin{array}{l}\begin{array}{l}\text { Before } \\
\text { Imputation }\end{array} \\
\begin{array}{l}\text { Odds ratio } \\
(95 \% \mathrm{Cl})\end{array}\end{array}$} \\
\hline & & & \\
\hline Age of clients & & $\begin{array}{l}0.99 \\
(0.96,1.02)\end{array}$ & $\begin{array}{l}0.98 \\
(0.95,1.02)\end{array}$ \\
\hline Sex of clients & $\begin{array}{l}\text { Female (=ref) } \\
\text { Male }\end{array}$ & $\begin{array}{l}- \\
0.92 \\
(0.57,1.49)\end{array}$ & $\begin{array}{l}- \\
1.32 \\
(0.67,2.58)\end{array}$ \\
\hline $\begin{array}{l}\text { Barriers to service } \\
\text { usage in the patient }\end{array}$ & & $\begin{array}{l}1.81 * * \\
(1.20,2.73)\end{array}$ & $\begin{array}{l}2.50 * * \\
(1.38,4.54)\end{array}$ \\
\hline $\begin{array}{l}\text { Lack of knowledge } \\
\text { of dialysis in case } \\
\text { managers }\end{array}$ & & $\begin{array}{l}0.91 \\
(0.62,1.36)\end{array}$ & $\begin{array}{l}1.00 \\
0.58,1.74)\end{array}$ \\
\hline $\begin{array}{l}\text { Period of case } \\
\text { management for the } \\
\text { patient }\end{array}$ & & $\begin{array}{l}1.02 \\
(0.93,1.12)\end{array}$ & $\begin{array}{l}1.05 \\
(0.92,1.19)\end{array}$ \\
\hline Work overload & & $\begin{array}{l}1.04 \\
(0.72,1.49)\end{array}$ & $\begin{array}{l}0.87 \\
(0.54, I .4 I)\end{array}$ \\
\hline $\begin{array}{l}\text { Lack of social resources } \\
\text { in the community } \\
\text { Lack of communication } \\
\text { with stakeholders }\end{array}$ & & $\begin{array}{l}1.34 \\
(0.83,2.15) \\
1.06 \\
(0.61,1.82)\end{array}$ & $\begin{array}{l}1.09 \\
(0.56,2.13) \\
1.10 \\
(0.52,2.32)\end{array}$ \\
\hline $\begin{array}{l}\text { Primary diseases of } \\
\text { kidneys }\end{array}$ & $\begin{array}{l}\text { CGN (=ref) } \\
\text { DN }\end{array}$ & $\begin{array}{l}- \\
1.25 \\
(0.65,2.43)\end{array}$ & $\begin{array}{l}- \\
I .66 \\
(0.7 I, 3.89)\end{array}$ \\
\hline & Others & $\begin{array}{l}1.32 \\
(0.45,3.89)\end{array}$ & $\begin{array}{l}2.44 \\
(0.68,8.79)\end{array}$ \\
\hline Nursing care level & & $\begin{array}{l}0.96 \\
(0.75,1.23)\end{array}$ & $\begin{array}{l}1.13 \\
(0.80,1.58)\end{array}$ \\
\hline $\begin{array}{l}\text { Physical malfunction of } \\
\text { the patient }\end{array}$ & & $\begin{array}{l}1.01 \\
(0.67,1.51)\end{array}$ & $\begin{array}{l}0.63 \\
(0.35,1.11)\end{array}$ \\
\hline $\begin{array}{l}\text { Cognitive malfunction } \\
\text { of the patient }\end{array}$ & & $\begin{array}{l}1.25^{*} \\
(1.00,1.55)\end{array}$ & $\begin{array}{l}1.28 \\
(0.94,1.74)\end{array}$ \\
\hline Caregiver's burden & & 1.35 & $1.60 *$ \\
\hline with caregiving & & $(0.97,1.87)$ & $(1.03,2.48)$ \\
\hline Model $\chi^{2}(=d f)$ & & $42.4(14)^{* * *}$ & $32.8(14)^{* *}$ \\
\hline $\mathrm{N}$ & & 391 & 204 \\
\hline
\end{tabular}

Note: $* P<0.05 ; * * P<0.01 ; * * * P<0.001$.

Abbreviations: $\mathrm{CGN}$, chronic glomerular nephritis; $\mathrm{Cl}$, confidence interval; DN, diabetic nephropathy.

disabled older adults ranged from $14 \%$ to $23 \%$. In a study of caregivers for disabled older adults in the US, $\mathrm{Li}^{35}$ found that the prevalence of unmet needs for respite care, home help, and personal care was $36 \%, 28 \%$, and $15 \%$, respectively. In a study by Naruse et al in Japan, ${ }^{37}$ the prevalence of unmet needs for home help and home nursing during the daytime reported by caregivers for persons certified with LTC insurance was $27 \%$ and $13 \%$, respectively. In a study by Nagata et $\mathrm{a}^{38}$ in Japan, the prevalence of unmet needs for visiting nursing rated by CMs in persons certified by LTC insurance was $18 \%$. Patients on dialysis are required to undergo dialysis, have fluid/dietary restrictions and a variety of medications,
Table 4 Factors related to unmet needs for daycare: logistic regression analysis

\begin{tabular}{|c|c|c|c|}
\hline \multirow[t]{2}{*}{ Variables } & \multirow[t]{2}{*}{ Categories } & \multirow{2}{*}{$\begin{array}{l}\text { After } \\
\text { imputation } \\
\text { Odds ratio } \\
(95 \% \mathrm{CI})\end{array}$} & \multirow{2}{*}{$\begin{array}{l}\begin{array}{l}\text { Before } \\
\text { Imputation }\end{array} \\
\begin{array}{l}\text { Odds ratio } \\
(95 \% \mathrm{Cl})\end{array}\end{array}$} \\
\hline & & & \\
\hline Age of clients & & $\begin{array}{l}1.02 \\
(0.99,1.05)\end{array}$ & $\begin{array}{l}1.02 \\
(0.98,1.06)\end{array}$ \\
\hline Sex of clients & $\begin{array}{l}\text { Female (=ref) } \\
\text { Male }\end{array}$ & $\begin{array}{l}- \\
2.17^{* *} \\
(1.33,3.52)\end{array}$ & $\begin{array}{l}- \\
2.02 * \\
(1.05,3.88)\end{array}$ \\
\hline $\begin{array}{l}\text { Barriers to service } \\
\text { usage in the patient }\end{array}$ & & $\begin{array}{l}2.92 * * * \\
(1.86,4.59)\end{array}$ & $\begin{array}{l}2.69 * * \\
(1.46,4.95)\end{array}$ \\
\hline $\begin{array}{l}\text { Lack of knowledge } \\
\text { of dialysis in case } \\
\text { managers }\end{array}$ & & $\begin{array}{l}0.78 \\
(0.5 \mathrm{I}, \mathrm{I} .20)\end{array}$ & $\begin{array}{l}0.69 \\
(0.39,1.22)\end{array}$ \\
\hline $\begin{array}{l}\text { Period of case } \\
\text { management for the } \\
\text { patient }\end{array}$ & & $\begin{array}{l}0.89 * \\
(0.81,0.99)\end{array}$ & $\begin{array}{l}0.91 \\
(0.80,1.04)\end{array}$ \\
\hline Work overload & & $\begin{array}{l}0.79 \\
(0.54,1.15)\end{array}$ & $\begin{array}{l}0.80 \\
(0.50,1.28)\end{array}$ \\
\hline $\begin{array}{l}\text { Lack of social resources } \\
\text { in the community }\end{array}$ & & $\begin{array}{l}1.52 \\
(0.94,2.47)\end{array}$ & $\begin{array}{l}1.59 \\
(0.83,3.05)\end{array}$ \\
\hline $\begin{array}{l}\text { Lack of communication } \\
\text { with stakeholders }\end{array}$ & & $\begin{array}{l}0.78 \\
(0.43,1.39)\end{array}$ & $\begin{array}{l}0.83 \\
(0.40,1.73)\end{array}$ \\
\hline $\begin{array}{l}\text { Primary diseases of } \\
\text { kidneys }\end{array}$ & $\begin{array}{l}\text { CGN (=ref) } \\
\text { DN }\end{array}$ & $\begin{array}{l}- \\
I .36 \\
(0.68,2.7 I)\end{array}$ & $\begin{array}{l}- \\
I .40 \\
(0.64,3.05)\end{array}$ \\
\hline & Others & $\begin{array}{l}2.11 \\
(0.69,6.44)\end{array}$ & $\begin{array}{l}2.52 \\
(0.76,8.43)\end{array}$ \\
\hline Nursing care level & & $\begin{array}{l}0.86 \\
(0.67,1.09)\end{array}$ & $\begin{array}{l}0.83 \\
(0.60,1.15)\end{array}$ \\
\hline $\begin{array}{l}\text { Physical malfunction of } \\
\text { the patient }\end{array}$ & & $\begin{array}{l}1.27 \\
(0.84,1.92)\end{array}$ & $\begin{array}{l}1.64 \\
(0.93,2.86)\end{array}$ \\
\hline $\begin{array}{l}\text { Cognitive malfunction } \\
\text { of the patient }\end{array}$ & & $\begin{array}{l}1.00 \\
(0.8 I, 1.24)\end{array}$ & $\begin{array}{l}1.02 \\
(0.76,1.36)\end{array}$ \\
\hline Caregiver's burden with & & 1.24 & 1.13 \\
\hline caregiving & & $(0.91,1.69)$ & $(0.75,1.70)$ \\
\hline Model $\chi^{2}(=d f)$ & & $59.7(14)^{* * *}$ & $31.7(14)^{* *}$ \\
\hline $\mathrm{N}$ & & 391 & 206 \\
\hline
\end{tabular}

Note: $* P<0.05 ; * * P<0.01 ; * * * P<0.001$.

Abbreviations: $\mathrm{CGN}$, chronic glomerular nephritis; $\mathrm{Cl}$, confidence interval; $\mathrm{DN}$, diabetic nephropathy.

and management of these health issues places multiple, complicated, and unavoidable demands on a patient's lifestyle. ${ }^{39}$ DPHD who cannot fully manage the treatments by themselves need to receive support by informal or formal caregivers. Additionally, Shimizu et $\mathrm{al}^{26}$ showed that each use of short stay and home-visit (e.g., home-help service and home-visit nursing) in a dialysis group was significantly lower than in a non-dialysis group under LTC insurance. Although measurement of unmet needs differs between this study and other studies, the prevalence of unmet needs for HCBS in DPHD may involve larger issues that should be resolved than the usual ones in disabled older adults. 
Table 5 Factors related to unmet needs for short stay: logistic regression analysis

\begin{tabular}{|c|c|c|c|}
\hline Variables & Categories & $\begin{array}{l}\begin{array}{l}\text { After } \\
\text { imputation }\end{array} \\
\text { Odds ratio } \\
(95 \% \mathrm{Cl}) \\
\end{array}$ & $\begin{array}{l}\begin{array}{l}\text { Before } \\
\text { Imputation }\end{array} \\
\begin{array}{l}\text { Odds ratio } \\
(95 \% \mathrm{Cl})\end{array} \\
\end{array}$ \\
\hline Age of clients & & $\begin{array}{l}1.00 \\
(0.98,1.03)\end{array}$ & $\begin{array}{l}1.00 \\
(0.96,1.04)\end{array}$ \\
\hline Sex of clients & $\begin{array}{l}\text { Female (=ref) } \\
\text { Male }\end{array}$ & $\begin{array}{l}- \\
I .48 \\
(0.9 I, 2.4 I)\end{array}$ & $\begin{array}{l}- \\
2.10^{*} \\
(1.04,4.22)\end{array}$ \\
\hline $\begin{array}{l}\text { Barriers to service } \\
\text { usage in the patient }\end{array}$ & & $\begin{array}{l}1.73 * \\
(1.09,2.74)\end{array}$ & $\begin{array}{l}1.94 * \\
(1.00,3.75)\end{array}$ \\
\hline $\begin{array}{l}\text { Lack of knowledge } \\
\text { of dialysis in case } \\
\text { managers }\end{array}$ & & $\begin{array}{l}1.15 \\
(0.75,1.74)\end{array}$ & $\begin{array}{l}1.55 \\
(0.87,2.77)\end{array}$ \\
\hline $\begin{array}{l}\text { Period of case } \\
\text { management for the } \\
\text { patient }\end{array}$ & & $\begin{array}{l}0.94 \\
(0.86,1.04)\end{array}$ & $\begin{array}{l}0.91 \\
(0.79,1.05)\end{array}$ \\
\hline Work overload & & $\begin{array}{l}1.16 \\
(0.78,1.71)\end{array}$ & $\begin{array}{l}1.07 \\
(0.64,1.76)\end{array}$ \\
\hline $\begin{array}{l}\text { Lack of social } \\
\text { resources in the } \\
\text { community }\end{array}$ & & $\begin{array}{l}1.31 \\
(0.76,2.26)\end{array}$ & $\begin{array}{l}1.03 \\
(0.5 I, 2.07)\end{array}$ \\
\hline $\begin{array}{l}\text { Lack of } \\
\text { communication with } \\
\text { stakeholders }\end{array}$ & & $\begin{array}{l}0.90 \\
(0.50,1.61)\end{array}$ & $\begin{array}{l}0.83 \\
(0.38,1.85)\end{array}$ \\
\hline $\begin{array}{l}\text { Primary diseases of } \\
\text { kidneys }\end{array}$ & $\begin{array}{l}\text { CGN (=ref) } \\
\text { DN }\end{array}$ & $\begin{array}{l}- \\
0.98 \\
(0.45,2.12)\end{array}$ & $\begin{array}{l}- \\
\text { I.34 } \\
(0.59,3.07)\end{array}$ \\
\hline & Others & $\begin{array}{l}1.17 \\
(0.36,3.81)\end{array}$ & $\begin{array}{l}1.74 \\
(0.44,6.78)\end{array}$ \\
\hline Nursing care level & & $\begin{array}{l}1.05 \\
(0.82,1.36)\end{array}$ & $\begin{array}{l}1.12 \\
(0.80,1.57)\end{array}$ \\
\hline $\begin{array}{l}\text { Physical malfunction of } \\
\text { the patient }\end{array}$ & & $\begin{array}{l}1.32 \\
(0.87,2.01)\end{array}$ & $\begin{array}{l}1.12 \\
(0.80,1.57)\end{array}$ \\
\hline $\begin{array}{l}\text { Cognitive malfunction } \\
\text { of the patient }\end{array}$ & & $\begin{array}{l}1.31 * \\
(1.05,1.64)\end{array}$ & $\begin{array}{l}1.29 \\
(0.71,2.33)\end{array}$ \\
\hline Caregiver's burden & & $2.42 * * *$ & 1.32 \\
\hline with caregiving & & $(1.73,3.38)$ & $(0.97,1.79)$ \\
\hline Model $\chi^{2}(=d f)$ & & $100.0(14)^{* * *}$ & $68.7(14)^{* * *}$ \\
\hline $\mathrm{N}$ & & 391 & 205 \\
\hline
\end{tabular}

Note: $* P<0.05 ; * * P<0.01 ; * * * P<0.001$.

Abbreviations: $\mathrm{CGN}$, chronic glomerular nephritis; $\mathrm{Cl}$, confidence interval; $\mathrm{DN}$, diabetic nephropathy.

In terms of the related factors, the prevalence of unmet needs for all four HCBS was significantly related to barriers to service usage in DPHD. In this study, having financial difficulties and being reluctant to accept formal services were included as barriers to service usage. In previous studies on older adults, unmet ADL/IADL needs were significantly related to lower income as enabling factors. ${ }^{11}$ In addition, resistance and reluctance of disabled persons or their caregivers to use services were also related to not using HCBS in previous studies. ${ }^{30,40-42}$ In DPHD, the same as in other disabled older adults, unmet needs for HCBS may be induced by these barriers to service usage.

Interestingly, nursing care level and physical ADL of patients did not significantly influence unmet need for all types of service, although more severe caregiver's burden with caregiving was significantly related to higher prevalence of unmet needs for home help and short stay. It is suggested that caregivers' need for assistance is not routinely assessed, although routine assessment pertains in care of the care receivers, and as a result, definitions of need for HCBS are usually given based on the care receivers' status, not the caregiver's needs. ${ }^{43}$ Additionally, LTC insurance in Japan emphasizes that anyone aged 65 years and older can receive benefits regardless of income and the availability of family support and they are certified as eligible only based on their functional and cognitive status. The fact that unmet needs for home help and respite short stay service were significantly influenced by caregivers' burden with caregiving, not by nursing care level or physical ADL of the patient may be related to a systematic inadequacy in assessment of needs of caregivers under LTC insurance.

According to this study, cognitive impairments of the patient were significantly related to unmet needs for short stay. Regarding DPHD, the need for respite service for caregivers of DPHD may be larger than for simple disabled older adults because burden with caregiving in their family caregivers is more serious because of giving support to medical adherence. However, usage of daycare and short stay seems to be difficult for persons with dementia because impaired cognitive functioning hinders adaptation to new environments. ${ }^{44}$ Accordingly, it is highly probable that caregivers of DPHD with severe cognitive impairments do not make full use of short stay to rest. On the other hand, this study showed that cognitive impairments of the patient had a significant association with unmet needs for visiting nursing. Previous studies in Western countries indicate that severe cognitive impairments were the factors most associated with non-utilization of care and treatment among disabled older adults. ${ }^{42,45} \mathrm{~A}$ study conducted in Japan also found that severe cognitive impairment was significantly related to unmet needs for visiting nursing. ${ }^{38}$ Medical adherence in dialysis among DPHD with severe cognitive impairments needs to be supported by visiting nursing as members of medical staff because of impairment in self-care. The results in this study suggest that visiting nursing cannot be used adequately to meet medical needs in DPHD with severe cognitive impairments.

Unmet need for daycare significantly differed by sex and period of case management for the patient. In fact, males 
compared to females were likely to have higher unmet needs for daycare. Previous studies showed that men have been less likely to use daycare not only among disabled persons, ${ }^{46}$ but also in general older adults, ${ }^{47}$ although a few studies in Japanese older adults showed that women have been more likely to show reluctance to use daycare. ${ }^{48}$ In this study, a shorter period of case management for the patient was likely to have resulted in higher unmet needs for daycare. Tashiro and Sugisawa indicated that those with higher disbelief in the effectiveness of elderly care services, related to several psychological factors, were more likely to not use daycare. ${ }^{49}$ Not only promotion of understanding of the effectiveness daycare but also forming trusting relationships through longer contacts between the patients and CMs may contribute to encouraging usage of daycare. In terms of lack of knowledge of dialysis in CMs, Sugisawa et $\mathrm{al}^{34}$ indicated that lack of knowledge of dialysis in CMs had a significant influence on barriers to CMs' effective performance of assessment, making plans, and monitoring/evaluation. In this study, lack of knowledge had a significant influence on unmet needs only for home help. Although not only visiting nursing, but also daycare and short stay are partly taken up by medical staff, home help services are done by non-medical staff. If CMs are not familiar with how to provide medical instructions regarding dialysis to non-medical staff who take up home help, it is possible that they hesitate to encourage usage of home help for DPHD with severe medical needs.

In terms of implications of this study for practice, we make some reference to three points. First, it is important for CMs to monitor unmet needs at a follow-up period after making care plans and coordinating LTC services because the prevalence of unmet needs for HCBS in DPHD may be higher than is usual in disabled older adults. Second, breaking this barrier needs to resolve unmet needs in DPHD as in the case of usual disabled older adults because barriers to service usage were associated with unmet needs similarly both in DPHD and usual disabled older adults. Third, CMs need to encourage HBCS use among patients with impaired cognitive function and caregivers who had heavier caregiving burdens, because heavier burden with caregiving and more severe cognitive malfunction of DPHD were important factors for the appearance of unmet needs, especially among DPHD.

\section{Limitations}

First, the external validity of the results is a concern because few studies have explored unmet needs for HCBS in DPHD. In addition, as utilization of LTC service is influenced by differences in LTC providing systems,${ }^{50}$ it remains unclear whether the findings obtained from this study will be just as valid for other countries. The external validity of the findings in this study needs to be examined not only in oriental countries including Japan but also in western countries. Second, this study has problems regarding sample selection. The prevalence of unmet needs for HCBS was evaluated by CMs of the patients certified by LTC insurance. A report indicates that the percentage of DPHD certified by LTC insurance in disabled patients was approximately 50\%-60\% in 2006 and 2011 surveys. $^{51}$ If these patients were included as study subjects, the prevalence of unmet needs for HCBS would be higher than the results in the present study. Third, only CMs evaluated unmet needs for HCBS in this study. A few studies indicated that agreement between patients' and family caregivers' rating of needs and agreement between patients/family caregivers' and experts' ratings of needs ranged from "poor" to "moderate". ${ }^{52,53}$ As it is unknown which one is more important for evaluating unmet needs for HCBS, studies on unmet needs rated by patients or their families are also needed. Fourth, influences of unmet needs on outcome indicators, such as health status and well-being of patients and their family need to be examined.

\section{Conclusion}

Barriers to service usage in the patients were associated with unmet needs for all of home help, visiting nursing, daycare, and short stay. Patients with more severe cognitive malfunction were more likely to have unmet needs for visiting nursing and short stay. Heavier burden with caregiving was associated with more likelihood of unmet needs for home help and short stay. CMs need to encourage HBCS use among patients with impaired cognitive function and caregivers who have heavier caregiving burdens.

\section{Acknowledgment}

This study was supported by the Research Fund for Fiscal 2015 created by the Japanese Association of Dialysis Physicians.

\section{Disclosure}

The authors report no conflicts of interest in this work.

\section{References}

1. Kutner NG, Brogan DJ. Assisted survival, aging, and rehabilitation needs: comparison of older dialysis patients and age-matched peers Arch Phys Med Rehabil. 1992;73(4):309-315.

2. Altintepe L, Levendoglu F, Okudan N, et al. Physical disability, psychological status, and health-related quality of life in older hemodialysis patients and age-matched controls. Hemodial Int. 2006;10(3):260-266.

3. Cook WL, Jassal SV. Functional dependencies among the elderly on hemodialysis. Kidney Int. 2008;73(11):1289-1295.

4. Piira T, Chow J, Suranyi MG. The role of cognitive factors in the adjustment of home dialysis carers. Psychol Health. 2002;17:313-322. 
5. Belasco AG, Barbosa D, Bettencourt AR, Diccini S, Sesso R. Quality of life of family caregivers of elderly patients on hemodialysis and peritoneal dialysis. Am J Kidney Dis. 2006;48(6):955-963.

6. The Japanese Society for Dialysis Therapy. Overview of regular dialysis treatment in Japan (as of 31 December 2013). Tokyo, 2014. Available from: http://docs.jsdt.or.jp/overview/pdf2014/p007.pdf. Accessed June 4, 2017.

7. Komesu I, Gima T, Tokashiki H, et al. [Examination of ADL in patients receiving hemodialysis]. J Jpn Soc Dialysis Ther. 2009;42(12):939-945. Japanese.

8. Alkema GE, Reyes JY, Wilber KH. Characteristics associated with home- and community-based service utilization for Medicare managed care consumers. Gerontologist. 2006;46(2):173-182.

9. You EC, Dunt D, Doyle C. How do case managers spend time on their functions and activities? BMC Health Serv Res. 2016;16:112.

10. Anderson RT, Bradham DD, Jackson S, Heuser MD, Wofford JL, Colombo KA. Caregivers' unmet needs for support in caring for functionally impaired elderly persons: a community sample. $J$ Health Care Poor Underserved. 2000;11(4):412-429.

11. Dubuc N, Dubois MF, Raiche M, Gueye R, Hébert R. Meeting the home-care needs of disabled older persons living in the community: does integrated services delivery make a difference? BMC Geriatr. 2011;11:67.

12. Lima JC, Allen SM. Targeting risk for unmet need: not enough help versus no help at all. J Gerontol B Psychol Sci Soc Sci. 2001;56(5): S302-S310.

13. Liu YH, Chang HJ, Huang CC. The unmet activities of daily living (ADL) needs of dependent elders and their related factors: an approach from both an individual- and area-level perspective. Int J Gerontol. 2012;6:163-168.

14. Casado BL, van Vulpen KS, Davis SL. Unmet needs for home and community-based services among frail older Americans and their caregivers. J Aging Health. 2011;23(3):529-553.

15. Guadagnoli E, Mor V. Daily living needs of cancer outpatients. J Community Health. 1991;16(1):37-47.

16. Siegel K, Raveis VH, Houts P, Mor V. Caregiver burden and unmet needs. Cancer. 1991;68(5):1131-1140.

17. Mor V, Allen S, Siegel K, Houts P. Determinants of need and unmet need among cancer patients residing at home. Health Serv Res. 1992;27(3):337-360.

18. Allen SM. Gender differences in spousal caregiving and unmet need for care. J Gerontol. 1994;49(4):S187-S195.

19. Meaney AM, Croke M, Kirby M. Needs assessment in dementia. Int J Geriatr Psychiatry. 2005;20(4):322-329.

20. Hancock G, Woods B, Challis D, Orrell M. The needs of older people with dementia in residential care. Int J Geriatr Psychiatry. 2006,21(1):43-49.

21. Stirling C, Andrews S, Croft T, Vickers J, Turner P, Robinson A. Measuring dementia carers' unmet need for services - an explanatory mixed method study. BMC Health Serv Res. 2010;10:122.

22. Black BS, Johnston D, Rabins PV, Morrison A, Lyketsos C, Samus QM. Unmet needs of community-residing persons with dementia and their informal caregivers: findings from the maximizing independence at home study. J Am Geriatr Soc. 2013;61(12):2087-2095.

23. Katz MH, Cunningham WE, Mor V, et al. Prevalence and predictors of unmet need for supportive services among HIV-infected persons: impact of case management. Med Care. 2000;38(1):58-69.

24. Patten SB, Williams JV, Lavorato DH, et al. Perceived met and unmet health-care needs in a community population with multiple sclerosis. Int J MS Care. 2012;14(1):2-8.

25. Sugisawa H, Liang J. Problems on health and welfare among elderly patients undergoing dialysis. In: Sugisawa H, Nishi S, Yamazaki T, editors. Life and Medical Care Among the Patients Undergoing Dialysis. Tokyo: Nippon Hyoron Sha; 2005:15-41 (in Japanese).

26. Shimizu U, Mitadera Y, Aoki H, Akazawa K. Dialysis patients' utilization of health care services covered by long-term care insurance in Japan. Tohoku J Exp Med. 2015;236(1):9-19.
27. Bradshaw J. Taxonomy of social need. In: McLachlan G, editor. Problems and Progress in Medical Care: Essays on Current Research, 7th series. London: Oxford Press; 1972:71-82.

28. LaPlante MP, Kaye HS, Kang T, Harrington C. Unmet need for personal assistance services: estimating the shortfall in hours of help and adverse consequences. J Gerontol B Psychol Sci Soc Sci. 2004;59(2): S98-S108.

29. Newcomer R, Amsberger P, Zhang X. Care management, client risk factors, and service use. Health Care Financ Rev. 1997;19(1): 105-120.

30. Brodaty H, Thomson C, Thompson C, Fine M. Why caregivers of people with dementia and memory loss don't use services. Int J Geriatr Psychiatry. 2005;20(6):537-546.

31. The Japanese Society for Dialysis Therapy. Overview of regular dialysis treatment in Japan (as of 31 December 2015). Tokyo, 2016. Available from: http://docs.jsdt.or.jp/overview/pdf2016/p002.pdf. Accessed June 10, 2017.

32. Lehning AJ, Kim MH, Dunkle RE. Facilitators of home and communitybased service use by urban African American elders. J Aging Health. 2013;25(3) 439-458.

33. Andersen R. Revisiting the behavioral model and access to medical care: does it matter? J Health Soc Behav. 1995;36(1):1-10.

34. Sugisawa H, Shimizu Y, Kumagai T, Sugisaki H, Ohira S, Shinoda T. Barriers to effective case management for disabled patients on hemodialysis. Ther Apher Dial. In press 2018.

35. Li H. Rural older adults' access barriers to in-home and communitybased services. Soc Work Res. 2006;30(2):109-118.

36. Li H, Morrow-Howell N, Proctor E. Assessing unmet needs of older adults receiving home and community-based services: conceptualization and measurement. J Soc Work Long-Term Care. 2005;3:103-120.

37. Naruse T, Nagata S, Taguchi A, Murashima S. Classification tree model identifies home-based service needs of Japanese long-term care insurance consumers. Public Health Nurs. 2011;28(3):223-232.

38. Nagata S, Taguchi A, Naruse T, Kuwahara Y, Murashima S. [Actual situation and characteristics of clients judged to need home-visiting nurse services by certified care managers and comparison of users and nonusers of such services]. Jpn J Public Health. 2010;57(12):1084-1093. Japanese.

39. Saran R, Bragg-Gresham J, Rayner HC, et al. Nonadherence in hemodialysis: associations with mortality, hospitalization, and practice patterns in the DOPPS. Kidney Int. 2003;64(1):254-262.

40. Winslow BW. Family caregivers' experiences with community services: a qualitative analysis. Public Health Nurs. 2003;20(5):341-348.

41. Arksey H, Glendinning C. Combining work and care: carers' decisionmaking in the context of competing policy pressures. Soc Policy Admin. 2008;42(1):1-18

42. Wolfs CA, de Vugt ME, Verkaaik M, Verkade PJ, Verhey FR. Empowered or overpowered? Service use, needs, wants and demands in elderly patients with cognitive impairments. Int J Geriatr Psychiatry. 2010;25(10): 1006-1012.

43. Anderson RT, Bradham DD, Jackson S, Heuser MD, Wofford JL, Colombo KA. Caregivers' unmet needs for support in caring for functionally impaired elderly persons: a community sample. J Health Care Poor Underserved. 2000;11(4):412-429.

44. Takai Y, Yamamoto-Mitani N, Okamoto Y, Fukahori H, Ko A, Tanaka M. Family caregiver strategies to encourage older relatives with dementia to use social service. $J A d v$ Nurs. 2013;69(12):2675-2685.

45. Philp I, McKee KJ, Meldrum P, et al. Community care for demented and nondemented elderly people: a comparison study of financial burden, service use and unmet needs in family supporters. $B M J$. 1995;310(6993):1503-1506.

46. Vecchio N, Fitzgerald JA, Radford K, Fisher R. The association between cognitive impairment and community service use patterns in older people living in Australia. Health Soc Care Community. 2016;24(3):321-333. 
47. Schneider AE, Ralph N, Olson C, Flatley AM, Thorpe L. Predictors of senior center use among older adults in New York city public housing. J Urban Health. 2014;91(6):1033-1047.

48. Tsukada N, Saito Y. Factors that affect older Japanese people's reluctance to use home help care and adult day care services. J Cross Cult Gerontol. 2006;21(3-4):121-137.

49. Tashiro K, Sugisawa H. [Factors related to adult daycare utilization among the elderly and their family care givers]. Jpn J Gerontol. 2010;32(1):3-13. Japanese.

50. Wu CY, Hu HY, Huang N, Fang YT, Chou YJ, Li CP. Determinants of long-term care services among the elderly: a population-based study in Taiwan. PLoS One. 2014;9(2):e89213.
51. Japan Association of Kidney Disease Patients. Nendo Ketsuekitosekikanja Jittaichosa Hokokusho [Report on survey hemodialysis patients 2011]. Setagaya-ku, Tokyo: Association of Periodical Publication by Organizations for the Disabled; 2012 (in Japanese).

52. Walters K, Iliffe S, Tai SS, Orrell M. Assessing needs from patient, carer and professional perspectives: the Camberwell Assessment of Need for Elderly people in primary care. Age Ageing. 2000;29(6):505-510.

53. Cleary M, Freeman A, Hunt GE, Walter G. Patient and carer perceptions of need and associations with care-giving burden in an integrated adult mental health service. Soc Psychiatry Psychiatr Epidemiol. 2006;41(3):208-214.
The International Journal of Nephrology and Renovascular Disease is an international, peer-reviewed open access journal focusing on the pathophysiology of the kidney and vascular supply. Epidemiology, screening, diagnosis, and treatment interventions are covered as well as basic science, biochemical and immunological studies. The manuscript management system is completely online and includes a very quick and fair peer-review system, which is all easy to use. Visit http://www. dovepress.com/testimonials.php to read real quotes from published authors.

Submit your manuscript here: https://www.dovepress.com/international-journal-of-nephrology-and-renovascular-disease-journal 